\title{
Determination of RBC membrane and serum lipid composition in trinidadian type II diabetics with and without nephropathy
}

\author{
B Shivananda Nayak' \\ Vishi Y Beharry' \\ Shivani Armoogam' \\ Melinda Nancoo' \\ Kevin Ramadhin' \\ Kiron Ramesar' \\ Ciara Ramnarine' \\ Anandi Singh' \\ Anisha Singh' \\ Kingsley Uche Nwachi' \\ Surujpaul Teelucksing ${ }^{2}$ \\ Ramesh Mathura ${ }^{3}$ \\ Lesley Roberts ${ }^{4}$ \\ 'Department of Preclinical Sciences, \\ Biochemistry Unit, ${ }^{2}$ Department of \\ Clinical Science, The University of the \\ West Indies, EWMSC, Trinidad and \\ Tobago; ${ }^{3}$ Department of Diagnostic \\ Laboratory Services, NCRHA, \\ EWMSC, Trinidad and Tobago; \\ ${ }^{4}$ Department of Medicine, Nephrology \\ Unit, NCRHA, EWMSC, Trinidad and \\ Tobago
}

Correspondence: B Shivananda Nayak The University of West Indies, Faculty of Medical Sciences, Dept of Preclinical Sciences, Biochemistry Unit, EWMSC, Champs Fleurs, Trinidad and Tobago Email shiv25@gmail.com

\begin{abstract}
Aim: The rheological properties of erythrocytes are impaired in diabetes mellitus, especially because of changes in their membrane lipid composition. The aim of this study was to determine and examine the relationship between red blood cell (RBC) membrane and serum lipid composition in type II diabetes subjects with and without nephropathy.

Methods: Trinidadian subjects aged 18-65 years were recruited for the study regardless of gender and ethnicity. Fasting blood samples were collected from 60 subjects of whom 20 were healthy individuals, 20 had type II diabetes without complications, and 20 were type II diabetics with nephropathy. Weight, height, waist/hip ratio, and blood pressure were recorded. All the blood samples were analysed to determine the serum lipid concentration, membrane lipid composition and plasma glucose concentration.

Results: The body mass index and the systolic blood pressure of the diabetics $\left(28.17 \pm 4.98 \mathrm{~kg} / \mathrm{m}^{2}\right.$, $153.21 \pm 22.10 \mathrm{mmHg})$ and those with nephropathy $(25.87 \pm 4.68,158.60 \pm 22.49 \mathrm{mmHg})$ were higher when compared with controls $(24.67 \pm 5.18,119.15 \pm 13.03 \mathrm{mmHg})$. The diabetic (175.89 $\pm 102.73 \mu \mathrm{g} /$ mgprotein) and diabetic nephropathy (358.80 \pm 262.66$)$ subjects showed significantly higher levels of RBC membrane cholesterol compared with controls (132.27 \pm 66.47). The membrane phospholipids, protein and $\mathrm{Na}^{+} / \mathrm{K}^{+} \mathrm{ATPase}$ concentrations were altered in diabetics and diabetic nephropathy patients when compared with controls. The trends of increased serum cholesterol and decreased high-density lipoprotein in diabetics and diabetic nephropathy patients were noted as compared with controls but they are not significant as expected. The low-density lipoprotein cholesterol was significantly higher in diabetics when compared with diabetic nephropathy and control subjects.

Conclusions: Our data suggest that there is a relationship between RBC membrane and serum lipid composition in subjects with type II diabetes with and without nephropathy. This relationship shows that diet and lifestyle plays a significant role in the alterations of the lipids both in serum and RBC membrane. The membrane and serum lipid composition may be used as possible indicators for type II diabetic patients with and without nephropathy to control their diet in the beginning stages to prevent them from further complications.
\end{abstract}

Keywords: RBC membrane, phospholipids, protein, diabetes, diabetic nephropathy

\section{Introduction}

Diabetes mellitus is a chronic metabolic disease, characterized by hyperglycemia with disturbances of carbohydrate, protein and fat metabolism due to an absolute or relative deficiency of insulin (Barcelo and Rajpathak 2001). Type II diabetes mellitus results from a combination of defective insulin secretion and insulin resistance, almost certainly involving the insulin receptor. Diabetic nephropathy is a syndrome occurring in people with diabetes mellitus, characterized by albuminuria, hypertension, and progressive renal insufficiency (Stedmans 2005). 
Diabetes mellitus is one of the most prevalent diseases in the developing world and the urgency for its management is increasing as the number of cases in these countries grows each year. In 2006, according to the World Health Organization (WHO), at least 171 million people worldwide suffered from diabetes and this figure is expected to double by the year 2030 (WHO 2007). Globally type II diabetes mellitus is the $3 \mathrm{rd}$ and 10th leading cause of loss of years of potential life among women and men respectively (Boyne et al 2006). A study done in 2001 among people 35-64 years old found that in Trinidad and Tobago, over $10 \%$ of the population had diabetes (Barcelo and Rajpathak 2001).

The red cell membrane contains approximately equal amounts of lipids and proteins. Membrane lipids are either phospholipids or neutral lipids, mostly unesterified cholesterol. Membrane phospholipids are asymmetrically arranged into a lipid bilayer two molecules thick. Choline phospholipids are more abundant in the extracellular surface whereas amino phospholipids are more concentrated on the inner leaflet of the bilayer. Cholesterol is intercalated between the phospholipid molecules. The relative amounts of cholesterol and phospholipids are responsible for the fluid properties of the erythrocyte membrane (Ballas and Krasnow 1980; Nagle and Tristram-Nagle 2000). Alterations in the membrane cholesterol-phospholipid ratio result in morphologically abnormal erythrocytes with decreased life span. Alterations in blood rheological properties have been reported in poorly controlled diabetes mellitus (Bryszewska et al 1986; Miossec et al 1999). Changes in lipid composition of RBC membranes resulting in an impairment of RBC deformability may play a role in an altered blood rheological pattern (Bakan et al 2006). There are few reports on the relationship between serum and RBC membrane lipid composition in other populations. Lee and colleagues (2004) showed that diet and general health status has close relation to the flow behavior of blood, which influences the circulation of the blood in the body. In their study they demonstrated that the high level of cholesterol, low-density lipoprotein (LDL) and high-density lipoprotein (HDL) in vivo alter the morphology and flow behavior of blood cells that can subsequently increase the risk of impairing physical function and microcirculation (Lee et al 2004). The present study has sought to determine and examine the relationship of the RBC membrane and serum lipid composition in Trinidadian type II diabetes with or without nephropathy (between the ages of 18-65 yrs). In addition, it has sought to determine the relationship between the RBC membrane and serum lipid composition in noninsulin-dependent diabetes mellitus
(NIDDM) patients in the multiethnic population of Trinidad, a third world country in the Americas.

This study has aimed to establish a link between the lipid composition of the RBC membrane and serum to aid in the early diagnosis and treatment of patients with type II diabetes mellitus, thus preventing the development of further complications including the impaired RBC deformability.

\section{Methods}

\section{Research design and method}

The objective of this case control study was to determine the impact of type II diabetes mellitus on RBC membrane and serum lipid composition among individuals between the ages of 18 and 65 in Trinidad. The study includes 60 subjects (male and female regardless of ethnicity) of which 20 were healthy individuals, 20 patients were type II diabetes, and 20 patients had type II diabetes and nephropathy.

The patients were recruited from the diabetic and nephrology clinic of various regional health centers of Trinidad and Tobago. The diabetics were selected on the basis of their fasting blood glucose value. The urea, creatinine, and microalbumin values were considered for including diabetic nephropathy patients in our study. The study was approved by the Ethics Committee for human experimentation (EC 59: 07/07-05/06), The Faculty of Medical Sciences, The University of the West Indies, St. Augustine. The blood pressure, height, weight (and resultant body mass index [BMI]), hip circumference, and waist circumference (and resultant waist/hip ratio) of all participants were recorded. Data was also collected by taking blood samples from which the following outcome attributes were measured: plasma glucose, serum total cholesterol, triglyceride (TG), LDL, HDL, RBC membrane composition (cholesterol, proteins, phospholipids, ATPase) and blood glucose.

\section{Determination of serum lipid composition}

The fasting blood sugar cholesterol, TG, HDL, and LDL cholesterol were estimated by fully automated analyzer (Vitros 250; Ortho-Clinical Diagnostics Inc., Rochester, NY, USA).

\section{Estimation of RBC membrane compositions \\ Processing of RBC}

The blood collected in purple colored tube was centrifuged for 10 minutes and the supernatant (plasma) was discarded. Two $\mathrm{mL}$ of normal saline was added to the tubes, mixed and 
centrifuged at $5000 \mathrm{~g}$ for 10 minutes. The supernatant was decanted and this procedure was repeated twice. Then $0.1 \mathrm{~mL}$ tris $\mathrm{HCl}$ buffer, $\mathrm{pH} 7.4$ (isotonic) was added and centrifuged for 5 minutes. This procedure was repeated three times. The clear cells obtained were suspended in a hypotonic buffer and stored at $4{ }^{\circ} \mathrm{C}$ for four hours. Afterwards the cells were washed again with hypotonic buffer and then centrifuged at $15,000 \mathrm{~g}$ and $10,000 \mathrm{~g}$ for 30 and 20 minutes, respectively. This procedure was continued until the solution became colorless. Two drops of isotonic buffer were added to the solution and it was homogenized to get the red cell membrane. This was used for the extraction lipids and determination of protein and $\mathrm{Na}^{+} \mathrm{K}^{+} \mathrm{ATPase}$ estimation.

\section{Extraction of lipids}

The red cell membrane collected was again centrifuged for 10 minutes at 15,000 g. The supernatant was decanted and the pellet obtained was suspended in $1 \mathrm{ml}$ of methanol and homogenized. The solution was made up to $5 \mathrm{ml}$ with the same methanol and centrifuged for 15 minutes at the same speed. The supernatant was decanted, added $14 \mathrm{ml}$ of chloroform to the tube and transferred in to a flat bottom flask. The content of this flask was evaporated in a fume hood. To the evaporated content, added $5 \mathrm{ml}$ of chloroform- methanol mixture to dissolve the solid and the resulting solution is poured into a labeled centrifuge tube and covered with paraffin. These tubes are centrifuged at $6000 \mathrm{rpm}$ and two differed layers of fluid were visible. The upper aqueous layer was aspirated and discarded while the lower layer was retained for lipid testing (Folch et al 1957). Aliquots of this layer were used for the estimation of cholesterol, phospholipids, and TG.

\section{Membrane cholesterol}

Lipid extract of $0.6 \mathrm{ml}$ was evaporated. Different standard concentrations ranging from 20,40, 60, 80, 100, and $120 \mu \mathrm{g}$ was used. Each standard of $0.05 \mathrm{~mL}$ was transferred from respective tubes to the tubes labeled S1 to S6 and evaporated. To these tubes (including the test) was added $3 \mathrm{ml}$ of ferric acetate uranyl acetate. The blank was run simultaneously. Sulphuric acid ferrous sulphate $2 \mathrm{ml}$ was added and the contents were mixed properly. The tubes were left standing for 20 minutes and their color intensity was read at $560 \mathrm{~nm}$. The cholesterol concentration of the test sample was determined using a standard graph plotted (Parekh and Jung 1970).

\section{Membrane phospholipids}

Lipid extract of $0.6 \mathrm{ml}$ was evaporated in a fume hood. Standard phosphate solutions of five different concentrations were used. A blank was run simultaneously. To all the tubes added $1 \mathrm{ml}$ of perchloric acid, $0.5 \mathrm{ml}$ of $3 \%$ ammonium molybdate (freshly prepared), and $0.5 \mathrm{ml}$ ascorbic acid (freshly prepared). The total volume of all the tubes was made up to $6 \mathrm{ml}$ with deionised water. All tubes were kept in boiling water for 6 minutes and the blue color developed was red at $710 \mathrm{~nm}$. The phospholipid concentration of the test sample was determined using a standard graph plotted (Rouser et al 1970).

\section{Membrane $\mathrm{Na}^{+} \mathrm{K}^{+} \mathrm{ATPase}$}

The membrane collected was used for the $\mathrm{Na}^{+} \mathrm{K}^{+}$ATPase. The membrane was made up to $1 \mathrm{ml}$ with isotonic buffer and added $0.2 \mathrm{ml}$ of $50 \mathrm{mM} \mathrm{MgSO}_{4}, 50 \mathrm{mM} \mathrm{KCl}, 1 \mathrm{mM}$ EDTA, and $40 \mathrm{mM}$ ATP solution. Blank was run along with it which contained the entire reagent except the red cell membrane. The tubes were equilibrated at $37^{\circ} \mathrm{C}$ for 10 minutes. To all the tubes added $0.1 \mathrm{ml}$ of enzyme solution at intervals of 3 minutes and the tubes were incubated at $37{ }^{\circ} \mathrm{C}$ for one $\mathrm{hr}$ in a water bath. After one hour, $1 \mathrm{ml}$ of ice cold 10\% TCA and $0.1 \mathrm{ml}$ of ANSA was added. The blue color developed was read at $620 \mathrm{~nm}$. The $\mathrm{Na}^{+} \mathrm{K}^{+} \mathrm{ATPase}$ concentration of the test sample was determined using a standard graph (Bonting 1970).

\section{Membrane protein}

Membrane suspension of $0.1 \mathrm{ml}$ was made up to $1.0 \mathrm{ml}$ with deionised water. $5.0 \mathrm{ml}$ of alkaline copper reagent was added, mixed well and allowed to stand for 10 minutes at room temperature. Standards solutions of bovine serum albumin range from $10-100 \mu \mathrm{g}$ and blank containing $1 \mathrm{ml}$ water were treated similarly. Folin-Ciocalteu reagent of $0.5 \mathrm{ml}$ was added very rapidly and mixed immediately. After two minutes the blue color developed was read at $640 \mathrm{~nm}$. Protein concentrations were expressed in $\mathrm{mg} / \mathrm{ml}$ of the membrane preparation (Lowry et al 1951).

\section{Sample specification}

The target population for this study consisted of individuals between the age of eighteen to sixty five years each, regardless of gender and race residing in Trinidad. There are three groups: A - control (healthy individuals); B - type II diabetics without nephropathy; and $\mathrm{C}$ - type II diabetics with nephropathy.

Individuals for group A were chosen from those patients screened at the diabetic clinics and proven to be healthy. Individuals for group B were chosen from those patients attending the diabetic clinics at the three previously 
mentioned hospitals. Individuals for group $\mathrm{C}$ were chosen from those patients attending the nephrology clinic at the same hospitals.

\section{Statistics and calculations}

Results were expressed as mean \pm standard deviation. Data were analyzed using the Statistical Package for Social Science (version 12.0; SPSS Inc., Chicago, IL, USA). The sample size calculated for this study was 22 per group, however due to logistic limitations we were only able to obtain 20 samples per group and hence the sample size used was 20. The comparisons within and among groups were done using Student's paired t- test and independent samples t-test. The $p$ value $<0.05$ was taken as the cut off level for significance. Pearson's correlation test was used to examine correlation.

\section{Results}

Table 1 and bar diagrams show the anthropometric and biochemical values for the three groups of subjects. The body mass index and the systolic blood pressure of the diabetics $\left(28.17 \pm 4.98 \mathrm{~kg} / \mathrm{m}^{2}, 153.21 \pm 22.10 \mathrm{mmHg}\right)$ and nephropathic diabetics $\left(25.87 \pm 4.68 \mathrm{~kg} / \mathrm{m}^{2}, 158.60 \pm 22.49 \mathrm{mmHg}\right)$ were higher compared with controls $\left(24.67 \pm 5.18 \mathrm{~kg} / \mathrm{m}^{2}, 119.15 \pm\right.$ $13.03 \mathrm{mmHg})$. The diabetic $(175.89 \pm 102.73 \mu \mathrm{g} / \mathrm{mg} /$ protein $)$ and diabetic nephropathy $(358.80 \pm 262.66 \mu \mathrm{g} / \mathrm{mg} /$ protein $)$ subjects showed significantly higher levels of RBC membrane cholesterol compared with controls (132.27 \pm $66.47 \mu \mathrm{g} /$ mgprotein) (Figure 1). The membrane phospholipids, protein and $\mathrm{Na}^{+} / \mathrm{K}^{+}$ATPase concentrations for controls were: $(9.17 \pm 9.23 \mu \mathrm{g} / \mathrm{mgprotein}, 0.94 \pm 0.47 \mathrm{mg} / \mathrm{mL}, 0.021 \pm$ $0.021 \mu \mathrm{moles} / \mathrm{ml})$ for diabetics: $(5.31 \pm 4.51 \mu \mathrm{g} / \mathrm{mg}$ protein, $0.65 \pm 0.38 \mathrm{mg} / \mathrm{mL}, 0.026 \pm 0.039 \mu \mathrm{moles} / \mathrm{ml})$, nephropathic diabetics: ( $19.67 \pm 14.83 \mu \mathrm{g} / \mathrm{mg}$ protein, $1.19 \pm 0.79 \mathrm{mg} / \mathrm{mL}$, $0.023 \pm 0.020 \mu \mathrm{moles} / \mathrm{ml}$ ), respectively (Figure 2). The trend of increased serum cholesterol and decreased HDL in diabetics $(206.85 \pm 47.34 \mathrm{mg} / \mathrm{dL}, 43.45 \pm 9.45 \mathrm{mg} / \mathrm{dL})$ and those with nephropathy $(209.90 \pm 66.13 \mathrm{mg} / \mathrm{dL}, 41.60 \pm 9.23 \mathrm{mg} / \mathrm{dL})$

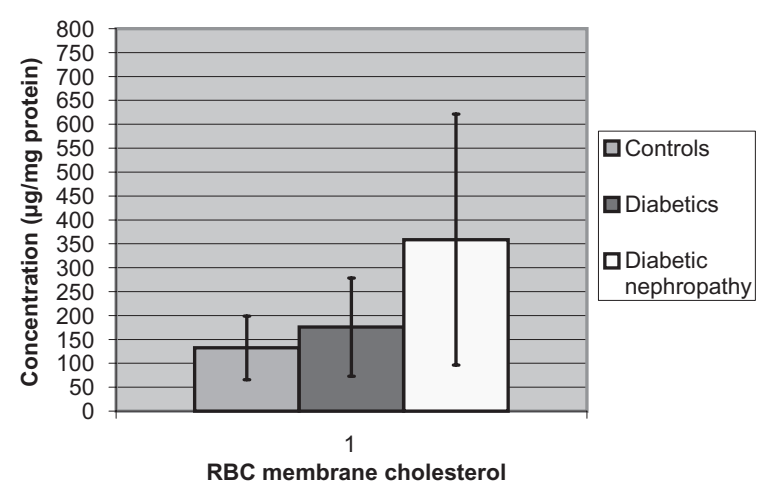

Figure I Graph showing membrane cholesterol means amongst the three groups.

were compared with controls $(184.50 \pm 35.69 \mathrm{mg} / \mathrm{dL}$, $48.05 \pm 12.42)$ but were not significant as expected. The LDL cholesterol was significantly higher in diabetics (131.00 \pm $35.63 \mathrm{mg} / \mathrm{dL}$ ) when compared with those with nephropathy $(116.40 \pm 54.03 \mathrm{mg} / \mathrm{dL})$ and the control subjects (118.70 \pm $37.75 \mathrm{mg} / \mathrm{dL})$.

The correlation between waist/hip ratio and blood pressure in diabetics and diabetics with nephropathy was not significant (Figure 3). There was an increase in the means of serum cholesterol in diabetics and diabetics with nephropathy, however there were no significant relationship when diabetics and diabetics with nephropathy were compared to controls ( $p=0.611$ and $p=0.415$, respectively) (Figure 4).

The mean values of RBC membrane cholesterol showed the same increase as serum cholesterol; however the relationship for this variable between controls and diabetics is not significant $(p=0.514)$ whereas, the relationship for this variable between diabetics and diabetics with nephropathy is significant $(\mathrm{p}=0.023)$ (Figure 5). The RBC membrane protein mean values was lower in diabetics $(0.65 \pm 0.38)$ compared with controls and a larger value in diabetics with nephropathy (1.19 \pm 0.79$)$ compared with controls $(0.94 \pm 0.47)$. The mean reading of $\mathrm{Na}^{+} / \mathrm{K}^{+}$ATPase activity was higher in diabetics with

Table I Means and standard deviations for the variables tested for controls, diabetics and diabetics with nephropathy

\begin{tabular}{llll}
\hline Variable & $\begin{array}{l}\text { Controls } \\
(\text { Mean } \pm \text { SD) } \\
\mathbf{n = 2 0}\end{array}$ & $\begin{array}{l}\text { Diabetics } \\
\text { (Mean } \pm \text { SD) } \\
\mathbf{n = 2 0}\end{array}$ & $\begin{array}{l}\text { Diabetes with nephropathy } \\
\text { (Mean } \pm \text { SD) } \\
\mathbf{n}=\mathbf{2 0}\end{array}$ \\
\hline Body mass index $\left(\mathrm{Kg} / \mathrm{m}^{2}\right)$ & $24.67 \pm 5.18$ & $28.17 \pm 4.98$ & $25.87 \pm 4.68$ \\
Waist/hip ratio & $0.85 \pm 0.06$ & $0.87 \pm 0.07$ & $0.91 \pm 0.07$ \\
Systolic blood pressure $(\mathrm{mmHg})$ & $119.15 \pm 13.03$ & $153.21 \pm 22.10$ & $158.60 \pm 22.49$ \\
Diastolic blood pressure $(\mathrm{mmHg})$ & $76.80 \pm 7.65$ & $94.93 \pm 10.62$ & $90.30 \pm 13.61$ \\
Glucose $(\mathrm{mg} / \mathrm{l00} \mathrm{mL})$ & $83.25 \pm 6.29$ & $120.55 \pm 41.20$ & $105.20 \pm 37.64$ \\
\hline
\end{tabular}




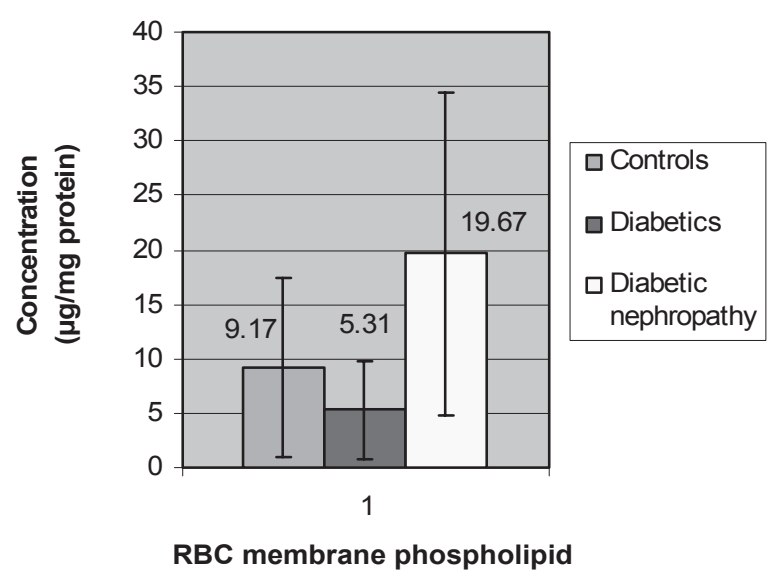

Figure 2 Graph showing red blood cell (RBC) membrane phospholipids means amongst the three groups.

nephropathy $(0.023 \pm 0.020)$ and much higher in diabetics $(0.031 \pm 0.039)$ when compared with controls $(0.021 \pm 0.021)$. The mean readings of $\mathrm{RBC}$ membrane phospholipids showed a decrease in diabetics $(5.31 \pm 4.51)$ but an increase in diabetics with nephropathy $(19.67 \pm 14.83)$ when compared with controls $(9.17 \pm 8.23)$.

The means of LDL showed an increase in diabetics (131.00 \pm 35.63$)$ and a decrease in diabetics with nephropathy $(116.40 \pm 54.03)$ when compared with controls (118.70 \pm 37.75) (Figure 6). The mean HDL readings decreased in diabetics $(43.45 \pm 9.45)$ and more in diabetics with nephropathy (41.60 \pm 9.23$)$ when compared with controls $(48.05 \pm 12.42)$ (Figure 6).

\section{Discussion}

The increase in body mass index and waist/hip ratio was expected since obesity is a known risk factor of diabetes. Blood pressure was also elevated in the diabetic group as compared to controls since increased blood pressure, in diabetics, is correlated with increased waist circumference. Blood pressure was elevated in diabetics with nephropathy

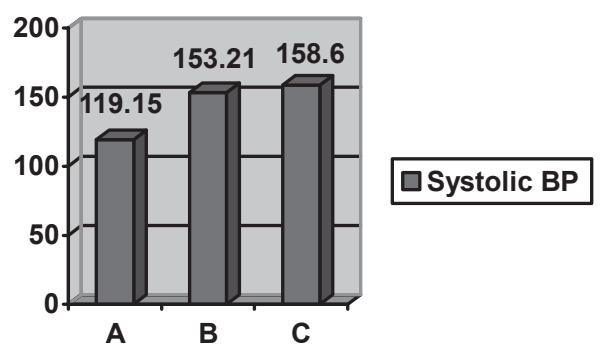

because angiopathy of renal glomeruli is an associated pathology.

Higher serum cholesterol in diabetics than controls could be attributed to the metabolism of acetate, a precursor to cholesterol, produced in increased amounts from the catabolism of fatty acids, carbohydrates and amino acids in the diet of this group (Talwar and Srivastava 2003). Serum cholesterol level was further elevated in diabetics with nephropathy since hypercholesterolemia is a constant feature of nephrotic syndrome (Kumar et al 2003). LDL-cholesterol increased in diabetics when compared to the control subjects from less than ideal management of diabetes, including poor diet control such as high intake of saturated fats and carbohydrates without the use of statins. In the diabetics with nephropathy the lower LDL-cholesterol was thought to be due to better disease management in these patients who attend a renal clinic and receive specialist attention. Decreased HDL levels in diabetics and an even further decrease in diabetics with nephropathy can be explained by reduced action of insulin at the tissue level and therefore insulin resistance (Valabhji and Elkeles 2003).

The increased RBC membrane cholesterol and altered phospholipid concentration in diabetics and diabetic nephropathy subjects when compared with controls may explain poor metabolic control. The increase in RBC membrane cholesterol in diabetics with and without nephropathy appears to reflect serum cholesterol.

Prisco and colleagues (1989) observed altered levels of RBC membrane phosholipid ratio in diabetics which could account for the impaired RBC deformability frequently reported in diabetes mellitus (Prisco et al 1989). Researchers also showed the relationship of altered RBC lipid composition and rheological impairment of the RBC (Garnier et al 1990). RBC membrane protein was decreased in diabetics when compared with controls and this could be due to damage of membrane proteins by nonenzymatic glycation

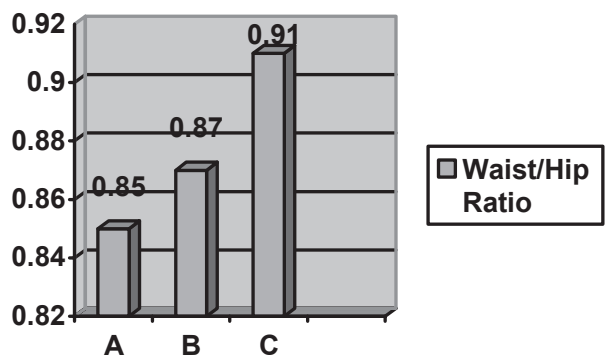

Figure 3 Graph showing comparison between systolic blood pressure (BP) and waist/hip ratio means amongst the three groups. 


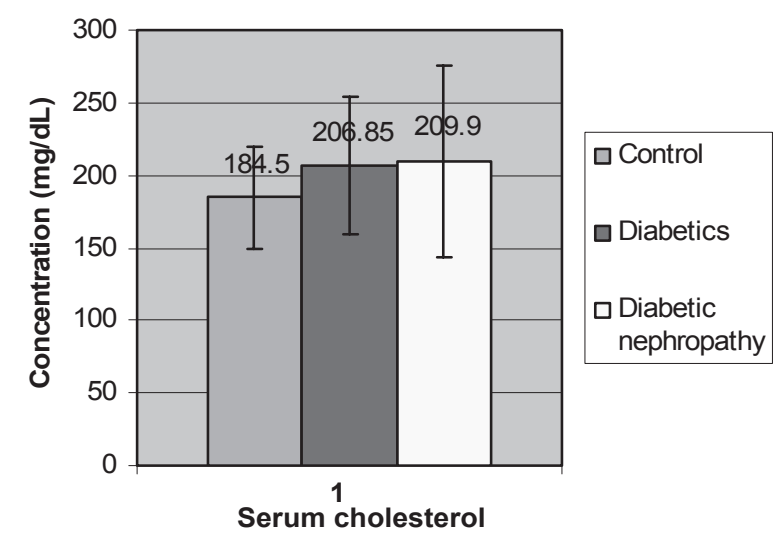

Figure 4 Graph showing serum cholesterol means amongst the three groups.

(Sampietro et al 1986; Watala et al 2005). In vitro studies of researchers demonstrated the decreased lipid fluidity in diabetics caused by nonenzymatic glycation of RBC membrane proteins (Watala 1988). RBC membrane protein was higher in the cases of diabetics with nephropathy, possibly due to the altered, healthier diets that diabetics with nephropathy are strictly advised to adhere to. Such diets would ensure that glucose levels were maintained within limits, thereby reducing $\mathrm{RBC}$ deformability. The decrease in membrane phospholipids in diabetics could have occurred from damage induced by nonenzymatic glycosylation of the cell membrane and subsequent loss of phospholipids from the RBC membrane (Ellenberg and Rifkin 1983). The management of diet and better disease control could have resulted in increased membrane phospholipids in the diabetics with nephropathy. Miossec and colleagues (1999) investigated the relationship between erythrocyte deformability, plasma lipids, lipid membrane composition, and cytosolic cations in poorly controlled type 2 diabetic patients and they concluded that in poorly controlled type 2 diabetic patients there is a

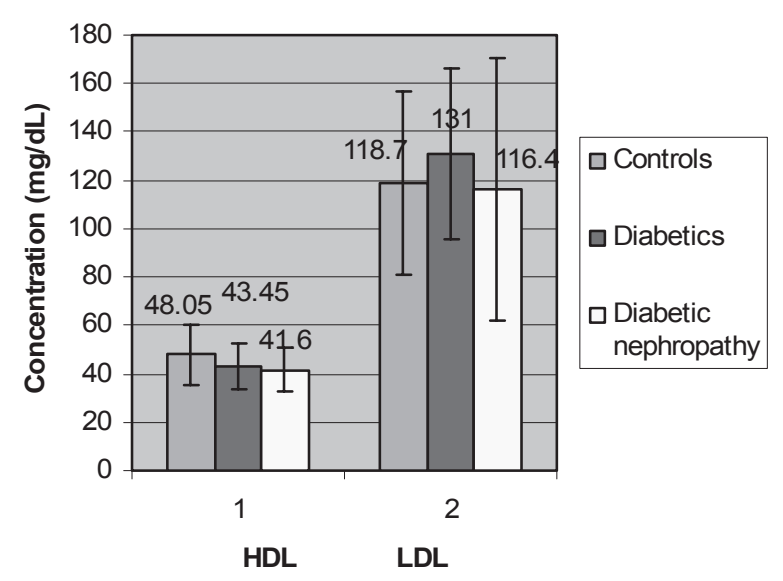

Figure 6 Graph showing comparison between HDL and LDL means amongst the three groups.

Abbreviations: HDL, high-density lipoprotein; LDL, low-density lipoprotein.

link between the chemical composition and the rheological properties of erythrocytes.

Our data suggest that there is a relationship between RBC membrane and serum lipid composition in subjects with type II diabetes with and without nephropathy. This relationship shows that diet and lifestyle plays a significant role in the alterations of the lipids both in serum and RBC membrane. Diet and management of diabetes plays a significant role not only in altering the lipid profile but also preventing rheological impairment of the RBC.

\section{Acknowledgments}

The study was funded by a Campus Research Fund, the University of West Indies. Authors extend their thanks to Miss Kezia Willie, and Dr. Celia Poon King, House officers, nursing staff and laboratory persons for their assistance during the study. Authors sincerely thank Prof. Lexley Pinto Pereira for editing the manuscript.

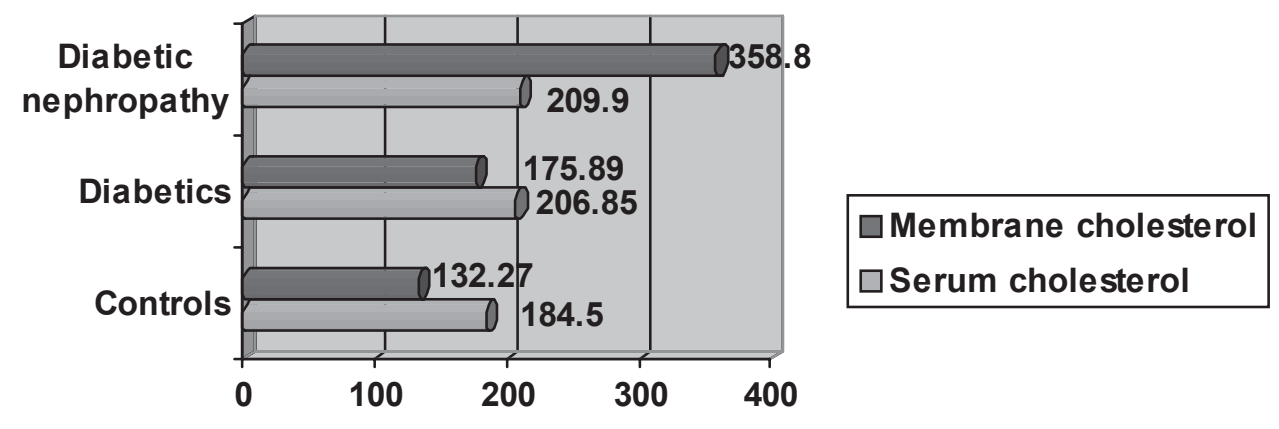

\section{Concentration ( $\mu \mathrm{g} / \mathrm{mg}$ protein)}

Figure 5 Graph showing comparison between serum cholesterol and red blood cell membrane cholesterol means amongst the three groups. 


\section{References}

Barcelo A, Rajpathak S. 2001. Incidence and Prevalence of diabetes mellitus in the Americas. Pan Am J Public Health, 10:300-8.

Ballas SK, Krasnow SH. 1980. Structure of erythrocyte membrane and its transport functions. Ann Clin Lab Sci, 10:209-19.

Bakan E, Yildirim A, Kurtul N, et al. 2006. Effects of type 2 diabetes mellitus on plasma fatty acid composition and cholesterol content of erythrocyte and leukocyte membranes. Acta Diabetologica, 43:109-13.

Bonting SL. 1970. In: Bilter EE (ed). Membrane and ion transport. London; Wiley Interscience, Vol. 1, p. 257.

Boyne M, Carter A, Doobay R, et al. 2006. The Caribbean Health Research Council Guidelines for Managing Diabetes in Primary Care in the Caribbean. 2nd edition. Caribbean Health Research Council.

Bryszewska M, Watała C, Torzecka W. 1986. Changes in fluidity and composition of erythrocyte membranes and in composition of plasma lipids in type I diabetes. Br J Haematol, 62:111-16.

Lee C-YJ, Kim K-C, Park H-W, et al. 2004. Rheological properties of erythrocytes from male hypercholesterolemia. Microvasc Res, 67:133-8.

Ellenberg M, Rifkin H. 1983. Diabetes Mellitus Theory and Practice. 3rd ed. New York: Medical Examination Publishing Co.

Folch JM, Lees M, Sloane Stanley GH. 1957. A simple method for the isolation and purification of total lipids from animal tissue. $J$ Biol Chem, 226:497-509.

Garnier M, Attali JR, Valensi P, et al. 1990. Erythrocyte deformability in diabetes and erythrocyte membrane lipid composition. Metabolism, 39:794-8.

Kumar V, Cotran R, Robbins S. 2003. Robbins Basic Pathology. 7th edition. Philadelphia: Saunders.

Lowry OH, Rosebrough NJ, Farr AL, et al. 1951. Protein measurement with the Folin phenol reagent. $J$ Biol Chem, 193:265-75.

Miossec PF, Zkhiri J, Pariès M, et al. 1999. Effect of pravastatin on erythrocyte rheological and biochemical properties in poorly controlled Type 2 diabetic patients; Diabet Med, 16:424-30.
Nagle JF, Tristram-Nagle S. 2000. Structure of lipid bilayers. Biochim Biophys Acta, 1469:159-95.

Parekh AL, Jung DH. 1970. Cholesterol determination with ferric acetate - uranium. Anal Chem, 42:1423.

Prisco D, Paniccia R, Coppo M, et al. 1989. Red blood cell lipid alteration in type II diabetes mellitus. Thromb Res, 54:751-8.

Rouser G, Fleischer S, Yamamoto A. 1970. Two dimensional thin layer chromatographic separation of polar lipids and determination of phospholipids by phosphorous analysis of spots. Lipids, 5:494-6.

Sampietro T, Lenzi S, Cecchetti P, et al. 1986. Nonenzymatic glycation of human platelet membrane proteins in vitro and in vivo. Clin Chem, $32: 1328-31$.

Stedman's (ed). 2005. Stedman's Medical Dictionary for the Health Professional and Nursing. 5th ed. Baltimore: Lippincott, Williams and Wilkins.

Talwar G, Srivastava L. 2003. Textbook of Biochemistry and Human Biology. New Delhi: Prentice Hall of India.

Valabhji J, Elkeles R. 2003. Dyslipidemia in type 2 diabetes: Epidemiology and biochemistry. Br J Diabetes Vasc Dis, 3:184-9.

Watala C, Pluta J, Golanski J, et al. 2005. Increased protein glycation in diabetes mellitus is associated with decreased aspirin-mediated protein acetylation and reduced sensitivity of blood platelets to aspirin. $J \mathrm{Mol}$ Med, 83:148-58.

Watała C. 1988. In vitro glycation of red blood cell proteins: high levels of glucose lower lipid fluidity of erythrocyte membranes. Exp Pathol, 33:233-8.

[WHO] World Health Organization. 2007. What is diabetes? (updated 2006) [online]. Accessed on November 14, 2007. URL: http://www. who.int/mediacentre/factsheets/fs312/en/index.html. 
